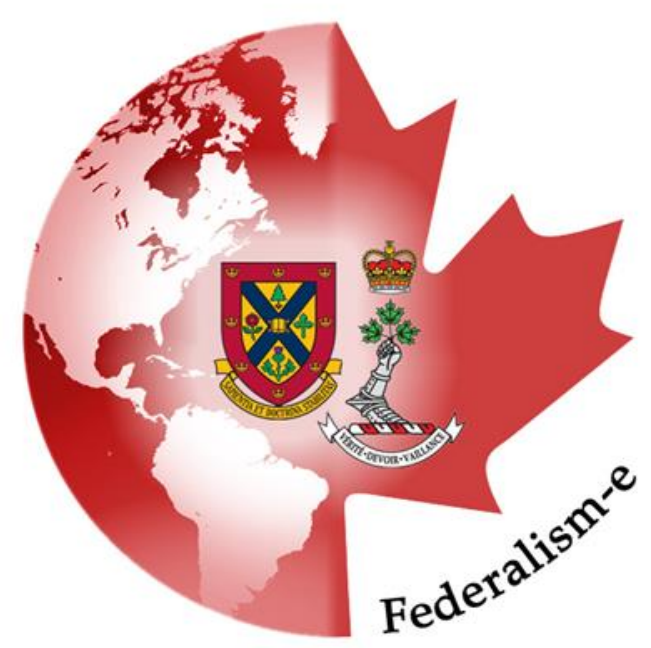

\title{
So Near Yet So Far: The Extent of Aboriginal Inclusion in Canada
}

\section{MELANIE GILLIS}

\section{Dalhousie University}

\section{Introduction}

The Truth and Reconciliation Commission of Canada (TRC) visited Halifax October 2011 to recount the atrocities which occurred in residential schools in Canada. For over one hundred years Aboriginal children attended these government-funded schools aimed at extinguishing the culture, spirituality, and knowledge of Aboriginal Peoples. ${ }^{1}$ Although extreme, the example of residential schooling demonstrates that Aboriginals were considered outsiders in Canada. While the schools themselves no longer exist, the debate about Aboriginals and the extent to which they are outsiders in the Canadian federal system persists. Political scientist Jennifer Smith (2004) contributes to this debate by describing who is 'in' and 'out' in terms of Canadian federalism.

\footnotetext{
${ }^{1}$ Truth and Reconciliation Commission of Canada, Residential Schools, 2011. Retrieved from ttp://www.trc.ca/websites/trcinstitution/index.php?p
} $=12$
Historical examples demonstrate that Aboriginals have succeeded in gaining more autonomy and self-determination over time. However, certain elements of Canadian federalism act as deterrents to full inclusiveness. While this question of inclusion raises countless issues surrounding the Aboriginal experience in Canada, this essay will focus on the following three key points relating to the inclusiveness of Canadian federalism. First, history shows that Aboriginals are on their way ' $i n$ '. This argument is supported by examples of Aboriginal title and Aboriginal self-determination being reclaimed over time. Second, the structure of Canadian federalism, if remained unchanged, will not allow for Aboriginals to be completely 'in'. In particular two key deterrents of Aboriginal inclusion will be discussed: territoriality and executive federalism. And finally, potential ways forward for Aboriginals will be considered, looking specifically at the merits of different selfgovernment models.

\section{On the Way 'In': The Evolution of Aboriginal Inclusion in Canada}

\subsection{Aboriginal Title}


'Netukulimk' is a Mi'kmaq term meaning 'stewardship of the land.' ${ }^{2}$ Originating from the Mi'Kmaq concept of Natural Law, wherein land and its resources are gifts from the Great Spirit, netukulimk signifies that land is communally owned and must be protected for the next generation's use. ${ }^{3}$ The land has always been an integral part of Aboriginal culture and spirituality, and so it is not surprising that land claims have become a central theme in the dialogue between the governments of Canada and Aboriginal Peoples. In terms of inclusiveness, the history of land claims in Canada shows us how far Aboriginals have come in regaining netukulimk, or 'stewardship' of their lands.

Only a little more than a century ago, the 1867 Indian Act gave the federal government exclusive authority to legislate in relation to "Indians and Lands Reserved for Indians". In 1911, Frank Oliver, then serving as Superintendent-General of Indian Affairs, amended the Indian Act to allow municipal governments to expropriate reserve lands for public works, and allow for a judge to move a reserve away from a municipality. ${ }^{4}$ While these examples show the inequalities faced by Aboriginals at this time, they also show how rapidly this imbalance has shifted over a single century. This shift was largely due to land claims. The 1997 case of Delgamuukw versus British Columbia exemplifies the use of land claims to further Aboriginal inclusion. This case, involving the Wet'suwet'en nation claiming aboriginal title over 58000 square kilometres of land in BC, went all the way to the Supreme Court. The Court found that under Section 35(1) of the Constitution Act rights to aboriginal title are protected by law, issuing the following statement: "Aboriginal title is a collective right by an Aboriginal group to the exclusive use and occupation of land for a variety of purposes,

\footnotetext{
${ }^{2}$ Suzanne Berneshawi, "Resource Management and the Mi'kmaq Nation," The Canadian Journal of Native Studies XVII, no. 1 (1997): 119.

3 Ibid., 120.

${ }^{4}$ Indian Act, 1911.
}

which need not be activities that the group has traditionally carried out on the land." ${ }^{5}$ This was a ground-breaking ruling because not only did the court officially recognize aboriginal title under the Constitution, but stated that it can be used for modern purposes and not simply traditional activities. Of course there are many other modern examples of land claims. The Yukon Territory for example finalized The Umbrella Final Agreement (UFA) in 1990 to return some 16 000 square miles of surface land to the fourteen nations in the Yukon Territory.

While the Oliver amendments demonstrate the lack of Aboriginal autonomy over lands only one hundred years ago, modern examples like the Yukon UFA and the Degamuukw case show how land claims have been a way 'in' for Aboriginals in Canada, and continue to be today. Aboriginals have always thought of the land as an extension of their culture, and therefore have always considered themselves as stewards of it in some respect. As Jennifer Smith says, "the notion of sovereignty past, present and future is [the Aboriginal's] political anchor, and a particularly weighty one when combined with land." ${ }^{\prime 6}$ But when it comes to federalism, the legal and political realms of Canada must also observe the rights to Aboriginal title if meaningful change is to occur.

\subsection{Aboriginal Rights}

In the 1969 White Paper on Indian Policy Pierre Trudeau argued that Aboriginals should not be afforded group-specific rights that separated them from the rest of Canada. ${ }^{7}$ The Paper is a clear representation of Trudeau's vision for a Pan-Canadian nationalism which would supersede all ethnic distinction. Indeed, one could argue that section 15(1) of the

\footnotetext{
${ }^{5}$ S.C.R. 1997, 1010.

6 Jennifer Smith, Federalism, (Vancouver: UBC Press, 2004), 67.

${ }^{7}$ Robert Murray, "Liberalism, Culture, Aboriginal

Rights: In Defence of Kymlicka," Canadian Journal of Philosophy 29 (1999): 109.
} 
Constitution Act (1982) contradicts any kind of asymmetrical federalism by saying that every individual "has the right to the equal protection and equal benefit of the law without discrimination." However political philosopher Will Kymlicka argues that without group-specific rights Aboriginals would not be equal under the law. He argues that unlike the majority, they need special laws to preserve their culture. ${ }^{8}$ This debate between Pan-Canadian symmetry and multinational asymmetry raises the obvious question of how Aboriginal rights have evolved over time. And when considering the ways in which Aboriginals are on their way ' $i n$ ' in terms of self-determination, this question is paramount.

Aboriginal rights, just like aboriginal title, have evolved drastically over a relatively short period of time. After all, it was not until 1985 that Bill C-31 "An Act to Amend the Indian Act" allowed for bands to determine membership based on their own rules instead of those dictated by the Indian Act. The Constitution Act of 1982 is perhaps the climax of Aboriginal inclusion in Canada- at least on paper. Section 25 of the Charter of Rights and Freedoms (1982) and section 35 of the Constitution (1982) show how Aboriginal rights have been entrenched in Canada's federal framework. For example, the Charter states that it will not derogate from "any aboriginal, treaty or other rights or freedoms that pertain to the aboriginal peoples of Canada," ${ }^{\prime 9}$ while the Constitution notes that "the existing aboriginal and treaty rights of the aboriginal peoples of Canada are hereby recognized and affirmed." ${ }^{10}$ In this way Kymlicka's assertion that in order to be included Aboriginals must receive special recognition is cemented in the Canadian Constitution, suggesting that in a formal legal sense Aboriginals are on their way 'in'. However, as Jennifer Smith explains, while Aboriginals are recognized constitutionally through the Charter

\footnotetext{
${ }^{8}$ Will Kymlicka, Liberalism, Community and Culture, (Oxford: Oxford University Press, 1989), 191.

${ }^{9}$ Canadian Constitution Act, Section 25, 1982.

${ }^{10}$ Canadian Constitution Act, Section 35, 1982.
}

and legally through Supreme Court rulings, the practical application of these rights is not as clear-cut. Indeed, there are many roadblocks to inclusiveness in the Canadian federal system which act as deterrents to Aboriginals being completely 'in'.

\section{Roadblocks to Inclusiveness: Deterrents in the Federal Framework}

\subsection{Territoriality}

Political scholar Donald Smiley describes the federal condition of Canada as a system where "major axes of social and political differentiation follow territorial lines."11 Simply put, Canada is essentially a territorial federation. Indeed, most federations follow this construction, and this is not by accident. In the realist perspective federations evolved to allow countries to expand their territory beyond the feasible control of a single central government. The previous section discussed the ways in which Aboriginals have become more included in the federal framework over time. While the progress made in terms of Aboriginal inclusion is clear, this process has been largely territorial in nature. That is, the majority of the concessions won have predominantly benefited territorially-based Aboriginals. The territoriality of the Canadian federal system deters the inclusion of nonterritorially-based Aboriginals, thereby thwarting their capacity to be fully included in the Canadian federal structure.

An example of a non-territorial group is Aboriginal women. Joyce Green suggests that Aboriginal women are actually canaries in the mines of Canadian citizenship: indicators for the condition of citizenship itself. In reference to Bill C-31, which gave band membership determination over to the bands themselves, Green argues that "where prior to 1985 the federal government implemented sexist, racist legislation", and after the Bill the bands themselves had adopted equally "sexist

${ }^{11}$ Donald Smiley, "Federal-Provincial Conflict in Canada," Publius 4 (1974): 7. 
membership codes."12 For example, in 1995 the Canadian Human Rights Commission had to step in and order the Montagnais Nation Council to pay damages to four women who had been discriminated against under Bill $\mathrm{C}-31 .{ }^{13}$ The Quebec band had placed a moratorium on giving Aboriginal women status under the Bill because they had not yet constructed their own formula for awarding band membership. ${ }^{14}$ The Native Women's Association of Canada's (NWAC) report on the Bill found that "although blatant discrimination against Indian women had been removed from the Act, the effects of that discrimination persisted, as new areas of inequality arose." ${ }^{15}$

Cheryl Maloney, President of the Nova Scotia branch of the NWAC, says that as an Aboriginal woman in Canada she feels that inclusiveness is impossible in the current federal environment. ${ }^{16}$ When asked whether Aboriginals in general are on their way 'in' Maloney says the band system involving the Indian Act and reserve lands is a backwards system that holds back change. According to her, reservations are but arbitrary boundaries drawn by the government that in no way define the Aboriginals around which they are drawn. The Aboriginal identity lies in 'nationhood', says Maloney, and has since time immemorial. Will Kymlicka describes this point of view perfectly, stating "if decisions about boundaries and powers are not made with the intention of empowering national minorities, then federalism may well worsen the position of national minorities." ${ }^{17}$ Nationhood goes beyond borders, and beyond generations. To divide this

12 Joyce Green, "Canaries in the Mines of Citizenship: Indian Women in Canada," Canadian Journal of Political Science 34, no. 4 (2001): 717.

${ }^{13}$ Margot Young, Poverty: Rights, Social Citizenship, and Legal Activism, (Vancouver: UBC Press, 2007), 115.

14 Ibid.

${ }^{15}$ Native Women's Association of Canada, Bill C-31

Amendment Literature Review, (2001), 7.

${ }^{16}$ Cheryl Maloney, "Interview on the Topic of Aboriginal Women's Inclusion in Canadian Federalism," Personal Communication, 13 Nov 2011. ${ }^{17}$ Kymlicka, Liberalism, Community and Culture, 138. by territories based on an outdated reserve system ultimately excludes many Aboriginals.

Of course Aboriginal women are not the only group being excluded on the basis of territoriality. Urban-dwelling Aboriginals who have no ties to reserves are also excluded. According to the 2001 census approximately "seven out of 10 Aboriginal people live off a reserve while another third of those live in large cities." ${ }^{18}$ While it is true that their rights and freedoms are protected under the Charter, the fact remains that their only other mode of inclusion would seem to be participation in one of the two levels of government. And as Jennifer Smith explains, "since Confederation less than a dozen Aboriginals have been elected to the House of Commons" and even fewer to the Senate. ${ }^{19}$ As we can see, the examples of both Aboriginal women and non-status Aboriginals demonstrate how the territoriality of Canada as a federation acts as a deterrent to complete Aboriginal inclusion in the system.

\subsection{Executive Federalism}

According to Donald Smiley executive federalism is "the relations between elected and appointed officials of the two levels of government." ${ }^{20}$ While executive federalism does allow for greater federal-provincial and interprovincial cooperation, the fact remains that it has resulted in a clear democratic deficit in Canada and, consequently, a clear deterrent to Aboriginal inclusion. It is true that Aboriginals have gained more autonomy over the past century, but they are still excluded by the intergovernmental summitry occurring through the use of executive federalism. Consider the

\footnotetext{
${ }^{18}$ Statistics Canada, "Aboriginal Peoples of Canada, Highlight Tables, 2001 Census," Cat. No. 97F0024XIE2001007, 2001. Retrieved from http://www12.statcan.ca/english/census01/Products/ standard/themes/DataProducts.cfm?S=1\&T=45\&ALEV $E L=2 \& F R E E=0$.

${ }^{19}$ Jennifer Smith, Federalism, 85.

20 lbid., 98.
} 
Meech Lake negotiations of 1987 which were criticized for failing to include Aboriginal voices, or the creation of the Social Union Framework Agreement (SUFA), where Aboriginal positions were largely ignored. ${ }^{21}$ But one of the clearest examples of the exclusion of Aboriginals is the creation of a Council of the Federation in 2003. Composed of the 13 premiers of the provinces and territories, the council was developed as "a new institution for a new era in collaborative intergovernmental relations" that would "foster meaningful relationships between governments."22 While the Council aims to show initiative on issues that are important to 'all Canadians', there is no mention of Aboriginal governments specifically. Abele and Prince discuss this failing, stating that the Council uses federalism to make Aboriginals seem like mockmunicipalities instead of fostering a nation-tonation relationship. ${ }^{23}$

However arguments have been made that existing structures can be modified to include Aboriginals in executive federalism. For example Abele and Prince suggest that the Council of the Federation should meet with peak Aboriginal Organizations of Canada, including groups like the NWAC and the Assembly of First Nations (AFN) to voice Aboriginal concerns. Cheryl Maloney however cautions against this. While these organizations allow Aboriginal voices to be heard, Maloney says there is a danger in treating representatives from these peak organizations as the elected representatives of Aboriginal Peoples instead of the elected officials of the nations, who are the rightful representatives of Aboriginals in Canada. ${ }^{24}$ As we can see there are as many ways forward as there are drawbacks to Aboriginal inclusion. This next

\footnotetext{
${ }^{21} \mathrm{~F}$ Abele and M Prince, "Constructive and Cooperative Federalism," IIGR, (Queen's University 11, 2003), 5.

22 Ibid.

23 Ibid.

${ }^{24}$ Maloney, "Interview on the Topic of Aboriginal Women's Inclusion in Canadian Federalism."
}

section will look at the merits, and cautions, of self-government as a way forward.

\section{The Way Forward: Devolution and the Merits of Self-Government}

\subsection{The Nisga'a Model}

In 2000, the Final Agreement of the Nisga'a People of the Nass Valley, BC went into effect. The Agreement allows the Nisga'a to become a self-governing nation, and was ground-breaking in terms of Aboriginal history because its laws have supremacy over federal and provincial law in specific areas. While the Nisga'a government's lawmaking powers still remain "concurrent with federal or provincial authority" they hold supremacy over eight zones of governance, including major areas such as lands and resources, health care, and social services. ${ }^{25}$ Nisga'a demonstrates how devolution, and self-government specifically, can bring Aboriginals within the fold of federalism. However this model gives a specific group of Canadians superiority over others, and thus could be interpreted as unconstitutional or asymmetrical according to the Canadian Charter of Rights and Freedoms and the equality it defends.

\subsection{The Public Government Model}

The territory of Nunavut was created in 1999 to settle self-government claims by the Innu people of the North. This model involves the creation of a territory in which the public can participate and elect representatives, including a premier, who will act as the voice of Nunavut in the Council of Federations and other such organizations. While the model of public government does allow for a more formal engagement with the federal system than the Nisga'a model, there are some concerns that because it is territorially-based it ignores the need for non-territorial Aboriginal groups, including women's groups and urban-dwelling

${ }^{25} N L G, 2$. 
Aboriginals, to be represented. To address this concern some countries have devolved power to an entire third level of government devoted to cultural affairs. Belgium, which has three distinct identity groups, uses this sort of governance scheme. However, this model may not be transferable to Canada given that there are hundreds of communities of Aboriginal People. There are also models of urban self-government being researched to address the underrepresentation of urban-dwelling Aboriginal groups. For example, Dunn suggests treating urban Aboriginals as a community of interest whose territory would be cultural rather than geographical, and whose jurisdiction would be defined accordingly. ${ }^{26}$

Whichever model you look at, it is important to note that self-government strategies do provide a useful way forward in terms of the inclusion of Aboriginals in the federal system. However they must come from the people themselves, or else run the risk of being yet another form of colonization.

\section{Conclusion}

"...there will be a day where Native people will get recognition, wherever they go, in all walks of life...because we will be educated enough and knowledgeable enough to know better."27 Marie Knockwood was one of the many Aboriginals who gave speeches at the Truth and Reconciliation Commission in Halifax. Her words suggest that there is hope for Aboriginals to be included, but that it will come from the ground up, beginning with education. Cheryl Maloney suggested something similar,

\footnotetext{
${ }^{26}$ M Dunn, "Access to Survival: A Perspective on Aboriginal Self-Government for the Constituency of the Native Council of Canada," NCC Constitutional Secretariat, Position Paper, Institute of Intergovernmental Relations (Kingston: Queen's University, 1986).

${ }^{27}$ Marie Knockwood, Live Stream Speech, Truth and Reconciliation Commission, (Halifax, 2011).
}

saying that Aboriginals will always have an idea that they are sovereign peoples, and that there is "an invisible line that connects a nation through time...through oral histories recounted by older generations..." $^{28}$ This essay discusses how Aboriginals are on their way in, but also considers clear deterrents in the federal framework that stop certain groups from being included. Finally ways forward were discussed, focusing on certain models for self-government. Of course due to the limited scope of this essay, more research exists on other ways forward that could not be included. Overall, Jennifer Smith is correct in saying that Aboriginals are on their way in. This is clear when we look the historical record of Aboriginal rights in Canada. But we are nowhere near close to achieving total inclusiveness for Aboriginals, especially for those who are not territorially-based. Nevertheless, both Maloney and Knockwood remain hopeful that there will come a day when Aboriginals will be fully included in Canada. What remains to be seen however is how Canadian federalism will need to adapt in order for Aboriginal inclusiveness to be fully realized.
${ }^{28}$ Maloney, "Interview on the Topic of Aboriginal Women's Inclusion in Canadian Federalism." 


\section{Bibliography}

Abele, F, and M Prince. "Constructive and Co-operative Federalism." IIGR, Queen's University 11, (2003).

Abele, Frances \& Prince, Michael. “Aboriginal governance and Canadian federalism: A to-do list for Canada," In New Trends in Canada Federalism, ed Francois Rocher and Miriam Smith. Peterborough: Broadview Press, 2003.

Aboriginal Affairs and Northern Development Canada (AANDC). (2011). http://www.aadncaandc.gc.ca/eng/1100100010002

Berneshawi, Suzanne. "Resource Management and the Mi'kmaq Nation." The Canadian Journal of Native Studies XVII, no. 1 (1997): 115-148.

Canadian Constitution Act. Sections 15, 25(1), 35. 1982.

Dunn, M. "Access to Survival: A Perspective on Aboriginal Self-Government for the Constituency of the Native Council of Canada." NCC Constitutional Secretariat, Position Paper, Institute of Intergovernmental Relations. Kingston: Queen's University, 1986.

Green, Joyce. "Canaries in the Mines of Citizenship: Indian Women in Canada." Canadian Journal of Political Science 34, no. 4 (2001): 715-738.

Knockwood, Marie. Live Stream Speech, Truth and Reconciliation Commission. Halifax, 2011.

Kymlicka, Will. Liberalism, Community and Culture. Oxford: Oxford University Press, 1989.

Ladner, Kiera L. "Negotiated inferiority: the Royal Commission on Aboriginal People's vision of a renewed relationship." The American Review of Canadian Studies 31, no. 1 and 2 (2001): 241.

Maloney, Cheryl. Interview on the Topic of Aboriginal Women's Inclusion in Canadian Federalism. Personal Communication, November $13^{\text {th }}, 2011$.

Murray, Robert. "Liberalism, Culture, Aboriginal Rights: In Defence of Kymlicka." Canadian Journal of Philosophy 29 (1): (1999), 109-138.

Native Women's Association of Canada. Bill C-31 Amendment Literature Review, 2001 Retrieved from http://www.nwac.ca/research/nwac-reports

Smiley, Donald. "Federal-Provincial Conflict in Canada." Publius 4, no. 3 (1974): 7-24. 
Smith, Jennifer. Federalism. Vancouver: UBC Press, 2004.

Statistics Canada. Aboriginal Peoples of Canada, Highlight Tables, 2001 Census. Cat. No. 97F0024XIE2001007, 2001. Retrieved from http://www12.statcan.ca/english/census01/Products/standard/themes/DataProducts.cfm?S=1 $\& T=45 \& A L E V E L=2 \& F R E E=0$

Truth and Reconciliation Commission of Canada. Residential Schools, 2011. Retrieved from http://www.trc.ca/websites/trcinstitution/index.php?p=12

Young, Margot. Poverty: Rights, Social Citizenship, and Legal Activism. Vancouver: UBC Press, 2007. 